\title{
Anemia Incidence in a Third Trimester Pregnant of Adolescent Pregnancy
}

\author{
Astri Wahyuningsih ${ }^{1 *}$, Piscolia Dynamurti Wintoro ${ }^{1}$, Wiwin Rohmawati ${ }^{1}$, \\ Yuriyahtun Khasanah ${ }^{1}$ \\ ${ }^{1}$ Department of Midwifery, STIKES Muhammadiyah Klaten, Klaten 57419, Indonesia \\ *Corresponding author. Email: astri@stikesmukla.ac.id
}

\begin{abstract}
Adolescent pregnancy is a pregnancy that occurs in young women aged 14-19 years old which are almost three times more at risk because they are mentally immature resulting in a lack of fulfillment of nutritional requirements during pregnancy. The incidence of anemia in pregnant women is quite high because most have not realized the importance of prevention of anemia and the danger posed. This study is aimed to determine the association between adolescent pregnancies and the incidence of anemia. This research method uses an analytical survey design with a cross-sectional approach. The population in this study is all third trimester pregnant women at Kemalang Health Center. This study used total sampling technique with a sample of 192 third trimester pregnant women. The result shows that pregnant women who are not suffering anemia are $11.4 \%$, those with mild anemia are $1.1 \%$, and those suffering from anemia are $0.5 \%$. For adult pregnant women, respondents who are not suffering from anemia is $78.6 \%$, and those with mild anemia is $8.4 \%$. The conclusion of this study is association between the adolescence pregnancy and the incidence of anemia in third trimester pregnant women with $\mathrm{p}$ value 0.034 . Teenagers take Health Counseling through Karang Taruna in their respective villages to avoid adolescent Pregnancy.

Keywords: adolescent pregnancy, anemia incidence, third trimester pregnant
\end{abstract}

\section{INTRODUCTION}

Adolescent pregnancy still becomes the major cause of mother and child mortality as well as health-sick intergenerational cycle and poverty [1]. Pregnancy of 15-19 years old girl has reached number of 48 from 1,000 pregnancies. The latest data show that there are 1.7 million girls under 24 years old who are giving birth each year [2]. Impacts arises from adolescent pregnancy are stunted fetal growth, premature delivery, low birth weight (BBLR), and delivery complication on mother. Pregnant adolescence almost three times at risk to suffer anemia [3].

Anemia risk on pregnant mother may cause miscarriage (abortus), premature delivery, stunted fetal growth inside womb, infection, hydatidiform mole, antepartum hemorrhage, as well as at delivery risks (his and push strength disturbance, prolonged 1st stage of delivery, prolonged 2 nd stage of delivery, placenta retention, and uterine atony). In addition, raised dangers to the fetus are intrauterine death, low birth weight (BBLR), birth with anemia, congenital defect, the baby is easily exposed with infection, and lastly death [4].

Based on the result of the research performed by researcher in Kemalang Health Center, it is obtained that in January until June there are 420 pregnant mothers consists of 156 third trimester pregnant mothers and among them there are $23(14.8 \%)$ pregnant adolescences. Result of $\mathrm{Hb}$ examination on the third trimester shows that there are 32 pregnant mothers who suffer from anemia and 7 of them (21.9\%) are pregnant adolescences. The purpose of this research is to establish association of adolescent pregnancy with anemia incidence on third trimester pregnant mother in Kemalang Health Center.

\section{METHOD}

This research uses analytic survey research method with cross-sectional approach. Population in this research is all of the third trimester pregnant mothers in Kemalang Health Center from July 1, 2018 - December 30, 2018 in number of 192 pregnant mothers. Sample in this research is 192 third trimester pregnant mothers in Kemalang Health Center which are chosen through total sampling technique. The instrument used in this research is documentation sheet (Laboratory Register Book) to find adolescent pregnancy data and anemia incidence. 


\section{RESULTS AND DISCUSSION}

Table 1 Association of adolescent pregnancy and anemia incidence

\begin{tabular}{|c|c|c|c|c|c|c|c|c|c|}
\hline \multirow{3}{*}{$\begin{array}{l}\text { Adolescent } \\
\text { Pregnancy }\end{array}$} & \multicolumn{9}{|c|}{ Anemia Incidence } \\
\hline & \multicolumn{2}{|c|}{$\begin{array}{l}\text { Not suffering } \\
\text { from Anemia }\end{array}$} & \multicolumn{2}{|c|}{$\begin{array}{c}\text { Mild } \\
\text { Anemia }\end{array}$} & \multicolumn{2}{|c|}{$\begin{array}{c}\text { Moderate } \\
\text { Anemia }\end{array}$} & \multirow[t]{2}{*}{ Total } & \multirow[t]{2}{*}{ Value } & \multirow[t]{2}{*}{$\mathbf{P}$} \\
\hline & $\mathbf{F}$ & $\%$ & $\mathbf{F}$ & $\%$ & $\mathbf{F}$ & $\%$ & & & \\
\hline Adolescent & 22 & 11.4 & 2 & 1.1 & 1 & 0.5 & 25 & 6.752 & 0.034 \\
\hline Adult & 151 & 78.6 & 16 & 8.4 & 0 & 0 & 167 & & \\
\hline Total & 173 & 90.0 & 18 & 9.5 & 1 & 0.5 & 192 & & \\
\hline
\end{tabular}

Based on Table 1, it obtains value of 6.752 and calculated $p$ value is 0.034 . Calculated $\mathrm{p}$ value compared to $\alpha$ value $=$ 0.05 so that $\mathrm{p}<\alpha(0.034<0.05)$ shows association of adolescent pregnancy with anemia incidence on third trisemester pregnant mothers in Kemalang Health Center in 2018.

Result of the research shows that from 192 respondents most of them are adult pregnant mothers (20-35 years old) in number of 167 respondents $(87 \%)$, they who are not suffering from anemia are 151 respondents $(78.6 \%)$ and they with mild anemia are 16 respondents $(8.4 \%)$. Meanwhile, there are adolescent pregnancy in number of 25 respondents (13\%), 22 of them $(11.4 \%)$ are not suffering anemia, 2 of them (1.1\%) have mild anemia, and 1 of them $(0,5 \%)$ has moderate anemia.

Result of this research is in line with the previous research [5] entitled "Association of Adolescent Pregnancy and Anemia in Cempaka Health Center Region of Banjar Baru City (Hubungan Kehamilan Remaja Dengan Anemia Di Wilayah Puskesmas Cempaka Kota Banjar Baru)". It showed that 18 respondents $(22.5 \%)$ were pregnant teenagers, 31 respondents $(37.8 \%)$ were suffering from anemia in their pregnancy and there were association of adolescent pregnancy with $\mathrm{p}$ value of anemia $=0.013<\propto=$ 0.05 .

Age may become risk factor of anemia incidence on pregnant mothers since age is related to women reproduction organs. Healthy and save age for pregnancy is $20-35$ years old. Pregnancy which occurs on age $<20$ years old may cause anemia since women development biologically have not yet optimal, their emotion is unstable, and they are not yet mentally ready so they are easily disturbed and causes lack of attention to their nutrition fulfilment. In addition, their body growth and nutrition which must be given to the fetus compete each other [6]. In adolescence, reproduction organs are not yet fully mature and in adolescent age, growth and development still occurs. Teenagers needs balance nutrition to achieve optimal growth and development. Adolescent pregnancy can disturb mother growth and development and then causes anemia, lack of nutrition, and low body endurance [7].

In pregnancy period, blood volume increases compared to non-pregnancy period. The increasing of plasma volume occurs in bigger proportion than the increasing of red blood cell. Consequently, hemodilution happens and leads to the decreasing of $\mathrm{Hb}$ concentration. Adolescent pregnancy gives double burden to the adolescent body since growth process and reproduction process happen simultaneously [8].
Anemia tends to occur on teenagers since their body which still needs to grow and develop must compete with nutrition given to the fetus. Consequently, it leads to fast decreasing of iron substance and nutrition. Pregnancy in age of $<20$ years old biologically has unstable emotion and not yet mentally ready. Hence, mothers are easy to be disturbed and causes lack of attention to nutrition's fulfillment during pregnancy [9].

Result of this research based on Chi Square analysis obtains value (probability measurement from the proof to refuse or accept Ho $)=6.752$ and $p$ value of $0.034(p<0.05)$ which means $\mathrm{Ha}$ is accepted and Ho is refused. It shows that there is association of adolescent pregnancy with anemia incidence on third trimester pregnant mother in Kemalang Health Center with record of adolescent pregnant mother with anemia and adult pregnant mother with anemia.

Mother's age is one of the causal factors of anemia on pregnant mother since age is closely related to nutrition fulfillment during pregnancy. Adolescent pregnant mothers tend to suffer from anemia since their body are still in growth and development and must compete with nutrition given to the fetus.

\section{CONCLUSION}

There is association between adolescent pregnancy and anemia incidence on third trimester pregnant mother in Kemalang Health Center with $p$ value of $0,034(p<0.05)$. In adolescence, growth and development of children is still ongoing so that if adolescent pregnancy occurs can disturb mother growth and development and then causes anemia, lack of nutrition, and low body endurance. So, adolescent pregnancy can be minimized by maturing the marriage age, the age of the woman at the time of marriage is 20 years. Future researchers should develop research variables regarding other factors that might cause anemia such as ANC adherence, parity, Fe tablet compliance, socioeconomic, and education.

\section{AUTHOR CONTRIBUTIONS}

Conceptualization (A.W, P.D.W); Material Research Preparation (A.W, P.D.W, W.R); Methodology (P.D.W, W.R); Data Collecting (Y.K); Data Analysis and Visualization (A.W, P.D.W, W.R, Y.K); Writing-original draft (A.W, P.D.W); Presentation (A.W). 
Cempaka Kota Banjarbaru,” J. vokasi Kesehat. Poltekkes Kemenkes Banjarmasin, vol. 1, pp. 114-118, 2013.

[1] Ma. S. Mohammad Ali Kiani, MAsumeh Ghanzanfarpour, "Adolescent Pregnancy: a Public Health Challenge,” Pediatría (Asunción), vol. 40, no. 3, pp. 207-208, 2013.

[2] BKKBN, “SDKI 2017," Survei Demografi dan Kesehatan Indonesia. 2017.

[3] T. Hadian, S. Mousavi, S. Meedya, S. MohammadAlizadeh-Charandabi, E. Mohammadi, and M.

Mirghafourvand, “Adolescent pregnant women's health practices and their impact on maternal, fetal and neonatal outcomes: A mixed method study protocol," Reprod. Health, vol. 16, no. 1, pp. 1-7, 2019.

[4] D. P. Jacqueline Frayne, "Anaemia in pregnancy.," R. Aust. Coll. Gen. Pract. 2019, vol. 48, no. 10, pp. 125-129, 2019.

[5] Hapisah dan Ahmad Rizani, "Kehamilan Remaja Terhadap Kejadian Anemia Di Wilayah Puskesmas
[6] E. Yilmaz, "The Impact of Iron Deficiency Anemia on Health Related Quality of Life in the Last Trimester of Pregnancy," Eurasian J. Med. Investig., vol. 3, no. 3, pp. 182-188, 2019.

[7] F. S. Papri, “Adolescent Pregnancy: Risk Factors, Outcome and Prevention," Chattagram Maa-O-Shishu Hosp. Med. Coll. J., vol. 15, no. 1, pp. 53-56, 2016.

[8] A. Kumar, T. Singh, S. Basu, S. Pandey, and V. Bhargava, "Outcome of teenage pregnancy," Indian J. Pediatr., vol. 74, no. 10, pp. 927-931, 2007.

[9] E. Desfauza, "Umur dan Paritas Ibu Berhubungan dengan Anemia pada Ibu Hamil di Klinik Bersalin Sumiariani Kec. Medan Johor Tahun 2016," J. Ilm. PANNMED, vol. 11, no. 3, pp. 154-157, 2017. 